\title{
PELAKSANAAN PUTUSAN ARBITRASE ASING PADA PERKARA PENANAMAN MODAL ASING DI INDONESIA (STUDI KASUS PERTAMINA VS KARAHA BODAS COMPANY)
}

\author{
Rachel Yohana ${ }^{1}$
}

\begin{abstract}
Arbitration by its advantages is often chosen by businessmen to resolve cases, however at the same time there are some weaknesses that actually do not make it as an efficient choice in resolving cases. Especially when the opposite parties are not cooperative and not upholding the spirit of arbitration. The refusal and annulment of foreign arbitral awards, for instance, has made a settlement process seems has no end and no legal certainty to enforcet its awards. In the case of PERTAMINA VS. Karaha Bodas Company, PERTAMINA made a claim of annulment of the arbitration award in Geneva, Switzerland on December $18^{\text {th }}, 2000$ at The Central Jakarta District Court. This claim was then accepted and the panel of judges decided to annul the a-quo arbitration award, its legal proceedings continued until the process by The Indonesia's Supreme Court. A wrong court award in responding to foreign arbitration awards may affect the consideration of foreign investment in a country, a bad precedent can damage the consideration of foreign investment. The findings of this study indicate PERTAMINA is not cooperative and does not support legal certainty for the implementation of foreign arbitral awards. Whereas the Awards of the Panel of Judges of the Central Jakarta District Court set a bad precedent and gave a negative impression on the consideration of arbitration and foreign investment in Indonesia. The Supreme Court Judge Panel in its award stated that it was not authorized by the Central Jakarta District Court to annul the a quo arbitration award is being a good precedent, indicating legal certainty in the implementation of foreign arbitration decisions and foreign investment in Indonesia.
\end{abstract}

Keywords: annulment of arbitration; enforcement of arbitration; foreign investment

\begin{abstract}
Abstrak
Arbitrase dengan berbagai kelebihannya kerap dipilih pelaku bisnis untuk menyelesaikan perkara yang timbul, namun bersamaan dengan itu beberapa kelemahan yang ada justru tidak menjadikannya sebagai pilihan yang efisien dalam menyelesaikan perkara. Terlebih ketika berhadapan dengan pihak yang tidak kooperatif, serta tidak menjunjung semangat berarbitrase. Upaya penolakan dan pembatalan putusan misalnya, menjadikan proses perkara seolah tidak ada habis-habisnya dan tidak ada kepastian hukum untuk melaksanakan putusan. Dalam perkara PERTAMINA VS. Karaha Bodas Company, PERTAMINA melakukan gugatan pembatalan putusan arbitrase Jenewa, Swiss tanggal 18 Desember 2000 ke Pengadilan Negeri Jakarta Pusat, gugatan ini kemudian diterima dan majelis hakim memutuskan batal putusan arbitrase a quo, upaya hukum berlanjut hingga proses peninjauan kembali. Putusan pengadilan yang keliru dalam menanggapi putusan arbitrase asing dapat berpengaruh pada pertimbangan penanaman modal asing di suatu negara, preseden buruk menjadikan negara seolah tidak ramah pada putusan
\end{abstract}

\footnotetext{
${ }^{1}$ Fakultas Hukum, Universitas Tanjungpura, Jl. Prof. Hadari Nawawi, Pontianak, Kalimantan Barat, e-mail: rachelyohana1997@gmail.com, tlp: 089647457096
} 
arbitrase asing. Temuan dari penelitian ini menunjukkan PERTAMINA tidak kooperatif dan tidak mendukung kepastian hukum bagi pelaksanaan putusan arbitrase asing. Sedangkan Putusan Majelis Hakim Pengadilan Negeri Jakarta Pusat menjadi preseden yang buruk dan menimbulkan kesan negatif terhadap pandangan berarbitrase dan penanaman modal asing di Indonesia. Majelis Hakim Mahkamah Agung dalam putusan peninjauan kembali yang tetap pada sikapnya menyatakan tidak berwenang Pengadilan Negeri Jakarta Pusat membatalkan putusan arbitrase a quo menjadi preseden yang baik, menunjukkan adanya kepastian hukum dalam pelaksanaan putusan arbitrase asing dan penanaman modal asing di Indonesia.

Kata Kunci: pelaksanaan putusan abitrase, pembatalan putusan, penanaman modal asing

\section{Pendahuluan}

Pada tanggal 28 November 1994 PERTAMINA, PLN dan Karaha Bodas Company L.L.C. melakukan perjanjian dalam 2 (dua) buah kontrak, yaitu Joint Operation Contract (JOC) dan Energy Sales Contract (ESC). Joint Operation Contract (selanjutnya disingkat JOC) merupakan kontrak kerjasama operasi antara PERTAMINA dengan Karaha Bodas Company L.L.C. (selanjutnya disebut KBC) dalam pengoperasian dan pengembangan energi geothermal guna menghasilkan tenaga listrik. Sedangkan Energy Sales Contract (selanjutnya disingkat ESC) merupakan kontrak antara PERTAMINA dengan PLN, bahwa PERTAMINA sebagai pihak penyedia tenaga listrik, sedangkan PLN sebagai pihak yang membeli listrik yang dihasilkan dari proyek JOC tersebut. Dalam melakukan kedua kontrak PERTAMINA dan PLN menjalankan kewenangan dari Negara sesuai dengan Undang-Undang No. 8 Tahun 1971 tentang Perusahaan Pertambangan Minyak Dan Gas Bumi Negara dan
Peraturan Pemerintah Nomor 17 Tahun 1990 tentang Perusahaan Umum (Perum) Listrik Negara, guna mewakili pemerintah dalam mengusahakan dan mengelola sumber daya bagi kepentingan umum. Sedangkan KBC merupakan konsorsium dengan penggabungan modal asing dan dalam negeri, yang berkantor di New York, USA dan Jakarta Selatan, Indonesia. Saham konsorsium KBC dimiliki oleh Caithness Energy, L.L.C. (40,5\%), FPL Group Inc. (40,5\%), Japan Tomen Power (9\%) dan mitra lokal PT Sumarah Daya Sakti (10\%). Meskipun dibuat atas kesepakatan bersama, namun kenyataan menunjukkan pelaksanaan kedua kontrak tidak berjalan mulus.

Di dalam setiap kontrak berlaku teori pacta sunt servanda yang telah menjadi asas dalam pelaksanaan kontrak, yang artinya bahwa setiap perjanjian yang dibuat berlaku sebagai Undang-undang bagi pembuatnya. Asas ini terdapat dalam Pasal 1338 Ayat (1) Kitab Undang-Undang Hukum Perdata yang berbunyi "Semua perjanjian yang 
dibuat secara sah berlaku sebagai undang-undang bagi mereka yang membuatnya". Menurut Herlien Budiono, adagium pacta sunt servanda (yang terkandung dalam Pasal 1338 Ayat (1) KUH Perdata, Pen-) diakui sebagai aturan yang menetapkan bahwa semua kontrak yang dibuat manusia satu sama lain, mengingat kekuatan hukum yang terkandung di dalamnya, dimaksudkan untuk dilaksanakan dan pada akhirnya dapat dipaksakan penataannya. ${ }^{2} \mathrm{Di}$ dalam kontrak JOC dan ESC terdapat klausula arbitrase yang menentukan bahwa apabila terjadi sengketa maka akan diselesaikan melalui forum arbitrase di Swiss. Pilihan penyelesaian sengketa melalui arbitrase yang telah dituangkan oleh para pihak ini merupakan pilihan hukum yang dikenal dengan "law of the parties", sehingga sepatutnya para pihak yang menjalankan proses arbitrase nantinya harus tetap menyadari akan pilihan hukum yang dipilih oleh para pihak yang bersengketa, yaitu sebagai bentuk penyelesaian yang bersifat damai, cepat dan terjaga kerahasiaan sengketa yang tengah dialami para pihak. ${ }^{3}$

Arbitrase merupakan salah satu bentuk dari Alternatif Penyelesaian

\footnotetext{
${ }^{2}$ Muhammad Syaifuddin. 2016. Hukum Kontrak: Memahami Kontrak dalam Perspektif Filsafat, Teori, Dogmatik, dan Praktik Hukum. Bandung: CV MANDAR MAJU, hlm. 91.

${ }^{3}$ Anita D.A Kolopaking. 2013. Asas Iktikad Baik Dalam Penyelesaian Sengketa Kontrak Melalui Arbitrase, Bandung: PT Alumni, hlm. 7.

162
}

Sengketa, forum arbitrase kerap dipilih guna menyelesaikan sengketa yang terjadi dalam transaksi bisnis nasional maupun internasional. $\mathrm{Hal}$ ini dikarenakan pihak berperkara berharap penyelesaiannya akan lebih cepat dan rahasia yang terjaga, terlebih putusan arbitrase menganut asas final and binding. Arbitrase memberikan kebebasan dan rasa aman dari ketidaktentuan sistem hukum yang berbeda, terlebih juga arbiter dalam menerapkan hukum yang berlaku dalam menyelesaikan perkara dan akan lebih memberikan perhatian terhadap keinginan, realitas, dan praktik dagang para pihak. ${ }^{4}$ Penyelesaian sengketa dilakukan oleh arbiter yang merupakan professional di bidangnya, hal ini menjadikan arbitrase sebagai proses penyelesaian sengketa yang ramah bagi pelaku bisnis. Kenyataan ini membuat banyak negara yang melakukan ratifikasi atas konvensi arbitrase internasional, termasuk Indonesia, guna menarik minat pemodal asing untuk menanamkan modalnya, sehingga baik perorangan, badan hukum swasta maupun milik pemerintah Indonesia menjadi terikat dengan asas resiprositas dalam pelaksanaan putusan arbitrase.

Terkait dengan kontrak yang dibuat antara PERTAMINA, PLN, dan KBC, permasalahan muncul ketika krisis

\footnotetext{
${ }^{4}$ Muhammad Syaifuddin, Op.cit., hlm. 380.
} 
moneter melanda negara-negara Asia. Pemerintah Indonesia dalam menangani krisis mengeluarkan Keppres No. 39 Tahun $1997{ }^{5}$ pada tanggal 20 September 1997 dan Keppres No. 5 Tahun $1998^{6}$ pada tanggal 10 Januari 1998 yang berisikan penangguhan beberapa proyek, termasuk di dalamnya adalah proyek JOC. Pihak PERTAMINA kemudian tidak memenuhi prestasinya dalam kontrak JOC dengan menyatakan bahwa dikeluarkannya Keppres merupakan kejadian force majeure dan dilakukan demi ketertiban umum. Namun pihak KBC merasa bahwa dikeluarkannya kedua Keppres bukan merupakan alasan bagi PERTAMINA dan PLN untuk tidak melaksanakan kontrak. KBC merasa dirugikan dan menolak untuk mengakui keberadaan kedua Keppres, serta menganggap PERTAMINA dan PLN telah wanprestasi, sesuai dengan kontrak yang telah dibuat maka pihak KBC melakukan gugatan wanprestasi terhadap PERTAMINA dan PLN ke forum arbitrase di Jenewa, Swiss. Tidak terima dengan kekalahannya di forum

\footnotetext{
${ }^{5}$ Keppres RI Nomor 39 Tahun 1997 tentang Penangguhan/Pengkajian Kembali Proyek Pemerintah, Badan Usaha Milik Negara, dan Swasta yang Berkaitan dengan Pemerintah/Badan Usaha Milik Negara.

${ }^{6}$ Keppres RI Nomor 5 Tahun 1998 tentang Pencabutan Keputusan Presiden Nomor 47 Tahun 1997 tentang Perubahan Status Pelaksanaan Beberapa Proyek Pemerintah, Badan Usaha Milik Negara dan Swasta yang Berkaitan dengan Pemerintah/Badan Usaha Milik Negara yang Semula Ditangguhkan atau Dikaji Kembali.
}

arbitrase Jenewa, Swiss, PERTAMINA mengajukan gugatan ke Pengadilan Negeri Jakarta Pusat, para pihak tetap bersikukuh pada pendapat awal masing-masing yang dikemukakan dalam forum arbitrase, hingga perkara berakhir pada proses Peninjauan Kembali oleh Mahkamah Agung.

Oleh karena itu dalam tulisan ini penulis akan membahas tentang pelaksanaan putusan arbitrase asing dalam perkara PERTAMINA melawan Karaha Bodas Company ${ }^{7}$ dalam kaitannya dengan penanaman modal asing di Indonesia, ditinjau dari preseden yang dibentuk pada putusan-putusan pengadilan, serta pengaruhnya terhadap pandangan berarbitrase dan penanaman modal asing di Indonesia.

\section{Analisis dan Pembahasan}

\section{A. Kepastian Hukum Pelaksanaan Putusan Arbitrase Asing Terkait Penanaman Modal Asing di Indonesia}

Arbitrase asing kerap dipilih oleh pelaku bisnis dikarenakan berbagai kelebihannya, pada asas final and binding misalnya, putusan arbitrase adalah final dan mengikat bagi para pihak. Jika dibandingkan dengan putusan pengadilan negara, maka sifat final adalah kelebihan daripada

\footnotetext{
${ }^{7}$ Putusan Arbitrase Jenewa, Swiss tanggal 18 Desember 2000 antara Karaha Bodas Company VS. PERTAMINA dan PLN.
} 
arbitrase, tidak ada upaya banding, kasasi, maupun peninjauan kembali pada proses arbitrase. Meskipun terdapat kemungkinan untuk dapat dibatalkannya putusan di negara tempat putusan dijatuhkan. Namun dengan batasan waktunya yang ada, ini menjadikan arbitrase lebih efisien dan efektif dalam menyelesaikan perkara yang diajukan, tanpa perlu mengulur waktu panjang yang merugikan pelaku bisnis.

Kelebihan lain daripada arbitrase asing adalah sifatnya yang universal, artinya suatu putusan dapat dilaksanakan dimanapun selama negara tersebut juga terikat pada perjanjian arbitrase untuk mengakui dan melaksanakan putusan daripada arbitrase asing (asas resiprositas). Sehingga ketika suatu putusan arbitrase asing ditolak pelaksanaannya di suatu negara, maka putusan tersebut tetap berlaku dan dapat dilaksanakan di negara lain. Berbeda dengan putusan pengadilan negara yang hanya dapat dilaksanakan di dalam yurisdiksi negara tersebut. Meskipun demikian, karena tidak memiliki dasar hukum untuk melaksanakan putusan yang dihasilkan, forum arbitrase membutuhkan peran negara untuk melaksanakan putusan yang telah dihasilkan.

Kedua asas yang dijelaskan di atas memberikan rasa kepastian, sebagaimana kepastian hukum menjadi salah satu indikator pertimbangan bagi pelaku usaha untuk menanamkan modalnya di suatu negara. Budiman Ginting dalam pidatonya yang berjudul Kepastian Hukum dan Implikasinya Terhadap Pertumbuhan Investasi di Indonesia menyebutkan bahwa:

"Kepastian hukum sebagai salah satu tujuan hukum tidak akan terlepas dari fungsi hukum itu sendiri. Fungsi hukum yang terpenting adalah tercapainya keteraturan dalam kehidupan manusia dalam masyarakat. Keteraturan ini yang menyebabkan orang dapat hidup dengan berkepastian, artinya orang dapat mengadakan kegiatan-kegiatan yang diperlukan dalam kehidupan bermasyarakat karena ia dapat mengadakan perhitungan atau prediksi tentang apa yang akan terjadi atau apa yang bisa ia harapkan. Dalam dunia usaha, kepastian hukum sangat diperlukan untuk menjamin ketenangan dan kepastian berusaha."

Berkaitan dengan pidato yang disampaikan Budiman Ginting, dapat kita pahami bahwa keteraturan menimbulkan kepastian, sehingga sesuatu dapat diprediksi. Sebagai contoh adalah keteraturan birokrasi perizinan, pelaksanaan kegiatan usaha, keteraturan masyarakat, hingga proses penyelesaian sengketa dan kepastian pelaksanaan putusannya. Berkaitan

\footnotetext{
${ }^{8}$ Budiman Ginting, 2008, "Kepastian Hukum dan Implikasinya Terhadap Pertumbuhan Investasi di Indonesia", Pidato Pengukuhan Jabatan Guru Besar Tetap dalam Bidang Ilmu Hukum Investasi pada Fakultas Hukum Universitas Sumatera Utara, Medan, 20 September.
} 
dengan penyelesaian sengketa dan kepastian pelaksanaan putusan, arbitrase kerap menjadi pilihan pelaku bisnis. Terhadap putusan arbitrase karena menganut final and binding, pihak dapat memprediksi bahwa putusan tersebut sudah pasti dapat dilaksanakan karena tidak terdapat upaya hukum. Bahkan sekalipun ditolak pelaksanaannya di suatu negara, maka putusan tersebut dapat diajukan pelaksanannya di negara yang lain. Inilah yang membedakannya dengan putusan pengadilan.

Arbitrase menjadi alternative penyelesaian sengketa yang ramah di bidang bisnis, sehingga disusun berbagai instrumen hukum di bidang arbitrase di Indonesia. Indonesia melakukan ratifikasi berbagai konvensi dan memberlakukan berbagai peraturan perundang-undangan guna menunjang arbitrase tadi. Hal ini adalah dalam upaya untuk menarik minat pemilik modal asing untuk menanamkan modalnya di Indonesia. Namun tetap dalam koridor yang saling menguntungkan antara negara dan pemilik modal.

Meskipun Indonesia telah memiliki berbagai perangkat peraturan dalam menunjang arbitrase, Indonesia masih dianggap sebagai negara yang tidak ramah terhadap putusan arbitrase asing. Pengadilan Indonesia dinilai cenderung mudah untuk menolak pelaksanaan putusan arbitrase asing apabila yang kalah adalah pihak lokal. Terlebih pada BUMN (State Owned Enterprise) yang ada, Indonesia cenderung masih menerapkan prinsip State Act Doctrine yang mana seharusnya menempatkan SOE tersebut sebagai badan hukum perdata ${ }^{9}$ justru dianggap sebagai negara yang tidak dapat digugat. Sehingga dalam beberapa pelaksanaan putusan arbitrase asing yang melibatkan pihak Indonesia, pelaksanaannya biasa diajukan di negara lain. Termasuk putusan Majelis Arbitrase Jenewa, Swiss yang melibatkan PERTAMINA, PLN dan Karaha Bodas Company.

Tindakan pengadilan yang cenderung mudah untuk menolak pelaksanaan putusan arbitrase asing dapat mempengaruhi penanaman modal asing di Indonesia. Pemilik modal asing bisa saja beranggapan bahwa Indonesia tidak ramah terhadap putusan arbitrase asing, tidak ada kepastian hukum dalam pelaksanaan putusannya. Padahal Pasal 3 Ayat (1) huruf a Undang-Undang Nomor 25 Tahun 2007 tentang

9 Ni'matul Huda. 1996. “Penerapan Prinsip Kekebalan Negara Terhadap Badan Usaha Milik Negara", Jurnal Hukum, 3 (5): 29. Sebaliknya, perlindungan atas dasar prinsip kekebalan perlindungan atas dasar prinsip kekebalan negara tidak dapat diberikan oleh suatu negara asing terhadap kepentingan nasional negara, apabila negara tersebut melakukan tindakan sebagai pedagang yang melakukan Commercial Act, artinya, negara berada dalam status iure gestionis. Dalam jure gestionis ini negara tidak lagi berdaulat, kedaulatannya telah dikurangi dan ia dapat dihadapkan di pengadilan asing (terjadi semacam erosi kedaulatan). 
Penanaman modal, menyebutkan bahwa

: "Penanaman modal diselenggarakan berdasarkan asas kepastian hukum". Budiman Ginting mengatakan bahwa yang dimaksud dengan asas kepastian hukum adalah asas dalam negara hukum yang meletakkan hukum dan ketentuan

peraturan perundang-undangan sebagai dasar dalam setiap kebijakan dan tindakan dalam bidang penanaman modal. Sehingga terdapat konsistensi peraturan dan penegakan hukum. Konsistensi ini ditunjukkan dengan peraturan yang tidak saling bertentangan serta dapat dijadikan pedoman untuk jangka panjang, sehingga tidak ada kesan pergantian peraturan yang mengikuti pergantian jabatan. ${ }^{10}$

Kepastian hukum juga ditunjukkan dengan bagaimana konsistensi lembaga penegak hukum di Indonesia terhadap ketentuan hukum yang ada. Dalam hal pelaksanaan putusan arbitrase asing misalnya, Indonesia sebagai negara yang telah meratifikasi Konvensi Pengakuan dan Pelaksanaan utusan Arbitrase Asing menjadi terikat dengan konvensi. Artinya Indonesia pun wajib untuk mengakui dan melaksanakan putusan arbitrase asing. Sikap yang cenderung menolak putusan arbitrase asing dapat mengakibatkan hilangnya semangat daripada kepastian hukum

10 Ibid.

166 tadi. Terlebih kepastian hukum merupakan perlindungan dari negara bagi para pemilik modal.

J. D. Nyhart, mengatakan bahwa hukum harus mengandung prinsip-prinsip predictability, procedural capability, codification of goals, education, balance, definition and clarity of status, serta accommodation agar hukum tersebut mampu berperan dalam menggerakkan ekonomi. Sehubungan dengan hal tersebut di atas, maka peraturan-peraturan investasi selayaknya memenuhi unsur-unsur teoretis yang dikemukakan Nyhart di atas. ${ }^{11}$

Hukum harus dapat diprediksi (predictability), peraturan yang ada harus dapat dilaksanakan dan ditegakkan dengan pasti. Misalnya dalam hal pelaksanaan suatu putusan arbitrase asing, jika putusan yang satu dapat dilaksanakan, maka putusan yang lain juga dapat dilaksanakan, selama sama-sama telah memenuhi persyaratan yang telah ditetapkan.

Kemudian terkait dengan kemampuan procedural (procedural capability), prosedur dalam penyelesaian sengketa misalnya, tidak boleh terlalu panjang dan berbelit-belit, seolah sulit untuk mencapai suatu kepastian. Pelaku bisnis akan merasa dirugikan dengan hal

\footnotetext{
${ }^{11}$ Erman Rajagukguk. 1995. Peranan Hukum dalam Pembangunan Ekonomi, Jilid 2, Jakarta: Universitas Indonesia, hlm. 365-367.
} 
ini. Penyelesaian sengketa harus dilakukan secara efektif dan efisien.

Misalnya terkait dengan pilihan penyelesaian sengketa dengan proses arbitrase, arbitrase asing menganut asas final and binding, serta hanya negara tempat putusan dijatuhkan yang berwenang untuk melakukan pembatalan. Prosedur yang tidak jelas, mencampuradukkan upaya pembatalan dan penolakan putusan menjadi salah satu tantangan dalam pelaksanaan putusan arbitrase asing. Karena ini menjadikan arbitrase menjadi pilihan yang tidak lagi efektif.

Codification of goals, hukum dibuat untuk pembangunan negara, pembangunan negara dilakukan untuk kepentingan orang banyak. Terkadang bisa saja terjadi benturan kepentingan, hal inilah yang menjadikan hukum seolah tidak pasti. Misalnya dalam kasus PERTAMINA, PLN dan KBC, yang mana terjadi benturan kepentingan antara Pemerintahan $\mathrm{RI}$ dengan KBC. Pemerintah dalam hal ini memiliki kepentingan untuk menyelamatkan perekonomian negara, sehingga menangguhkan berbagai proyek yang ada, termasuk ESC dan JOC. Sedangkan perusahaan memiliki kepentingan untuk melaksanakan proyek, memperoleh keuntungan yang seharusnya didapat, dan terhindar dari kerugian daripada penangguhan proyek tersebut.
Kemudian terkait dengan unsur pendidikan (education), pendidikan dalam hal ini dicontohkan dengan sosialisasi dan fasilitas transparansi bagi masyarakat umum terkait penanaman modal. Edukasi berupa sosialisasi terkait penanaman modal akan menjadikan informasi tersebut transparan. Dimulai dari perangkat regulasi yang ada, keterbukaan akses informasi menjadikan semua komponen merasa percaya dengan hukum yang ada. Unsur yang selanjutnya adalah keseimbangan (balance), hukum harus mampu menciptakan keseimbangan. Misalnya dalam hal pengaturan penanaman modal, peraturan yang dibuat harus menjaga keseimbangan antara kepentingan investor dengan kepentingan masyarakat luas. Kepentingan investor perlu dihormati, namun tidak boleh mengabaikan kepentingan negara.

Artinya harus memperhatikan keseimbangan daripada kepentingan masing-masing pihak. Penanaman modal perlu memperhatikan kepentingan kedua belah pihak, tidak hanya kepentingan negara penerima modal, namun juga investor. Sebagaimana dalam prinsip hukum ekonomi internasional, yaitu prinsip perlakuan sama (identical treatment) dan prinsip penyelesaian sengketa secara damai perlu diperhatikan dalam melaksanakan penanaman modal asing. 
Definition and Clarity of Status, dalam penanaman modal harus ada definisi, pengaturan dan status yang jelas bagi para investor dalam menjalankan usahanya, tanpa membedakan apakah itu investor asing maupun dalam negeri.

Accomodation, hukum harus dapat mengakomodasi keseimbangan, definisi dan status yang jelas bagi kepentingan individu-individu atau kelompok-kelompok dalam masyarakat. ${ }^{12}$

\section{B. Pacta Sunt Servanda, Filosofi Kooperatif, dan Konsep Ketertiban Umum dalam Pelaksanaan Putusan Arbitrase Asing}

Melihat pada perkara pelaksanaan putusan arbitrase asing yang menyangkut PERTAMINA dan KBC adalah jelas bahwa PERTAMINA sebagai pihak yang kalah tidak menunjukkan sikap yang kooperatif untuk menerima dan melaksanakan putusan arbitrase a quo, hal ini terbukti dengan berbagai proses hukum yang diajukannya, dimulai dari gugatan pembatalan putusan di Pengadilan Swiss hingga peninjauan kembali di Mahkamah Agung Republik Indonesia.

Putusan arbitrase memiliki sifat yang final dan mengikat, sehingga bagaimanapun putusannya maka harus dihormati dan dilaksanakan

12 Budiman Ginting, Op.cit., hlm. 9-10.

168 sebagaimana telah diperjanjikan dalam kontrak yang telah dibuat. Sikap PERTAMINA yang seolah tidak ada keinginan secara sukarela untuk melaksanakan putusan arbitrase a quo mencerminkan sikap yang tidak kooperatif dan tidak menghormati asas executorial kracht. Sikap ini juga tidak sesuai dengan teori pacta sunt servanda, yang mana bahwa setiap perjanjian yang telah dibuat adalah mengikat layaknya undang-undang. Teori filosofi kooperatif dan pacta sunt servanda berkaitan erat dengan asas iktikad baik, dalam hal ini PERTAMINA tidak memiliki iktikad baik untuk melaksanakan putusan arbitrase $a$ quo. Sebelumnya PERTAMINA bersama-sama dengan PLN dan KBC telah bersepakat bahwa apabila timbul sengketa dalam kedua kontrak yang dibuat, maka akan diselesaikan dengan arbitrase, ketentuan tersebut mengikat, sehingga tidak ada ruang bagi pengadilan untuk memeriksa perkara yang timbul di kemudian hari.

PERTAMINA dalam gugatan pembatalan putusannya di Pengadilan Negeri Jakarta Pusat mendalilkan bahwa putusan arbitrase a quo adalah melanggar ketertiban umum, sehingga tidak dapat dilaksanakan, dan menjadi batal. Ketertiban umum memiliki konsep yang terlalu abstrak, sehingga sangat tergantung pada penilaian hakim. Memang bahwa asas ketertiban umum merupakan asas fundamen dalam 
Konvensi New York 1958. Asas tersebut ditegaskan dalam Pasal V ayat (2) huruf b yang berbunyi "the recognition or enforcement of the award would be contrary of the public policy of that country". Oleh karena ketertiban umum sebagai salah satu asas dalam Konvensi, memberi kewenangan bagi negara yang diminta eksekusi, untuk menolak pengakuan dan pelaksanaan apabila putusan bertentangan dengan ketertiban umum negara yang bersangkutan. Namun, perlu diketahui bahwa putusan arbitrase a quo tidak pernah didaftarkan eksekusinya di Indonesia, sehingga tidak ada kewenangan bagi Majelis Hakim Pengadilan Negeri Jakarta Pusat untuk menilai putusan arbitrase a quo.

Seperti yang telah ditegaskaan oleh Sudargo Gautama bahwa pemakaian lembaga ketertiban umum adalah hanya sebagai tameng, tidak sebagai pedang untuk menghilangkan hukum asing. Dengan kata lain, fungsi dari lembaga ketertiban umum hanya untuk perlindungan agar sendi-sendi hukum nasional tidak dilanggar, bukan untuk meniadakan pemakaian daripada hukum asing. Akibat dari diakuinya lembaga ketertiban umum, namun tidak memiliki konsep yang konkrit ini mengakibatkan putusan menjadi riskan untuk ditolak pelaksanaannya di negara pihak yang dikalahkan dalam berperkara, meskipun secara materil putusan tersebut bisa dilaksanakan. Kehadiran konsep ketertiban umum membuat kepastian hukum dalam pelaksanaan putusan arbitrase asing menjadi lemah. Perihal pelaksaanaan putusan arbitrase a quo, putusan a quo adalah sudah sepantasnya dilaksanakan. PERTAMINA seharusnya beriktikad baik untuk melaksanakan putusan arbitrase selayaknya melaksanakan kontrak yang telah dibuat. Tindakan PERTAMINA dengan mengajukan gugatan pembatalan putusan arbitrase a quo di Pengadilan Federal Swiss adalah telah sesuai dengan New York Convention 1958, sebagaimana seat arbitrase yang ditentukan dalam kontrak adalah Swiss. Namun, gugatan tidak ditindaklanjuti lantaran PERTAMINA tidak membayar uang deposit. Proses hukum pembatalan ke Pengadilan Negeri Jakarta Pusat bukanlah tindakan yang tepat, lantaran Pengadilan Negeri Jakarta Pusat tidak berwenang untuk membatalkan putusan arbitrase a quo, terlebih putusan tersebut tidak pernah didaftarkan eksekusinya di Indonesia. Sehingga putusan Pengadilan Negeri Jakarta Pusat dianggap tidak memiliki kekuatan hukum di pengadilan-pengadilan di negara tempat putusan arbitrase diajukan pelaksanannya. Sehingga eksekusi daripada putusan arbitrase a quo tetap dapat dilaksanakan di negara-negara 
tempat putusan dimohonkan eksekusi, kecuali di Indonesia.

\section{Akibat Pembatalan Putusan Arbitrase Asing terhadap Pandangan Berarbitrase dan Penanaman Modal Asing di Indonesia}

Putusan arbitrase adalah putusan yang final dan mengikat, serta dapat dilaksanakan di manapun selama negara bersangkutan terikat pada Konvensi Arbitrase Asing. Pada perkara PERTAMINA VS. KBC putusan arbitrase a quo secara jelas menyatakan bahwa PERTAMINA telah wanprestasi dan wajib membayar sejumlah kerugian yang ditimbulkan. Persoalan muncul ketika Pengadilan Negeri Jakarta Pusat menerima gugatan pembatalan putusan arbitrase a quo yang diajukan PERTAMINA, serta membatalkan putusan arbitrase a quo dengan alasan pelanggaran ketertiban umum. Sedangkan menurut Pasal V ayat (1) huruf e Konvensi New York 1958, dikatakan bahwa suatu putusan arbitrase hanya dapat dibatalkan oleh otoritas yang berwenang menurut negara tempat suatu putusan arbitrase dibuat. Sehingga berdasarkan ketentuan tersebut, tidak tepat bahwa Pengadilan Negeri Jakarta Pusat membatalkan putusan arbitrase $a$ quo. Perkara berlanjut hingga proses peninjauan kembali, yang mana Mahkamah Agung tetap pada pendiriannya bahwa Pengadilan Negeri
Jakarta Pusat tidak memiliki kewenangan membatalkan putusan arbitrase a quo dan membatalkan putusan Pengadilan Negeri Jakarta Pusat tanggal 27 Agustus 2003 No. 86/PDT.G/2002/PN.JKT.PST.

Terhadap tindakan Majelis Hakim Pengadilan Negeri Jakarta Pusat, perlu dipahami bahwa antara pembatalan putusan dengan penolakan eksekusi adalah dua hal yang berbeda. Mengutip Suleman Batubara dan Orinton Purba dalam bukunya yang berjudul Arbitrase Internasional terdapat perbedaan antara pembatalan dan penolakan putusan arbitrase menurut Hikmahanto Juwana, antara lain :

1. Upaya hukum pembatalan diistilahkan dengan annulment/set aside, sedangkan upaya hukum penolakan diistilahkan dengan refusal.

2. Pengaturan, syarat-syarat, alasan-alasan antara upaya hukum pembatalan dan penolakan adalah berbeda satu sama lain. Pengaturan dan syarat serta alasan upaya hukum pembatalan diatur dalam suatu peraturan perundang-undangan suatu negara, sedangkan upaya hukum penolakan diatur dalam suatu perjanjian internasional yang kemudian ditransformasikan ke dalam undang-undang nasional suatu negara.

3. Akibat hukum dari diterimanya upaya hukum pembatalan berbeda dengan upaya hukum penolakan. Dikabulkannya upaya hukum pembatalan mengakibatkan putusan 
arbitrase tersebut dinafikan (dianggap tidak pernah ada putusan arbitrase), sedangkan akibat hukum dikabulkannya upaya hukum penolakan adalah tidak berarti dinafikannya keputusan arbitrase tersebut. Jadi, apabila suatu putusan arbitrase ditolak oleh lembaga pengadilan suatu negara, pihak yang ditolak (menang) tersebut masih dapat mengajukannya kembali ke negara tempat di mana aset dari pinak yang dikalahkan berada.

4. Dikabulkannya upaya hukum pembatalan mengharuskan para pihak untuk mengulang kembali proses arbitrase (re-arbitrate), sedangkan apabila upaya hukum penolakan dikabulkan tidak mengharuskan para pihak untuk mengulang kembali proses berarbitrase.

5. Dikabulkannya upaya hukum pembatalan tidak serta merta memberikan kewenangan bagi pengadilan untuk memeriksa dan memutus sengketa tersebut.

6. Alasan dari upaya hukum pembatalan lebih mengacu kepada substansi sengketa, sedangkan alasan upaya hukum penolakan tidak demikian. Dengan kata lain, alasan dari suatu penolakan lebih mengacu kepada prosedural bukan substansial.

7. Penolakan keputusan arbitrase lebih didasarkan pada tidak adanya yurisdiksi dari pengadilan di mana arbitrase tersebut dimohonkan untuk diakui dan dilaksanakan, sedangkan upaya hukum pembatalan tidaklah demikian.

Pembatalan putusan adalah kewenangan daripada pengadilan tempat suatu putusan arbitrase dijatuhkan, tidak ada hak untuk membatalkan putusan bagi negara tempat putusan arbitrase diajukan eksekusi. Terkait dengan konsep ketertiban umum yang didalilkan, Pengadilan Negeri Jakarta Pusat hanya berwenang untuk menolak pelaksanaan putusan, sedangkan pada kenyataannya putusan arbitrase a quo tidak pernah didaftarkan pelaksanaannya di Indonesia. Kesan buruk berupa pembatalan putusan arbitrase dengan menyalahi aturan yang ada tentunya dapat berpengaruh pada keinginan pemodal asing untuk menanamkan modalnya di Indonesia. Per tahun 2019, meskipun Indonesia menjadi negara penerima modal asing terbesar kedua di ASEAN setelah Singapura, namun perlu diperhatikan akibat tidak adanya kepastian hukum dan perlindungan kepentingan investor, bisa menjadikan investor mengalihkan arus modal ke negara ASEAN lainnya. ${ }^{13}$

Tindakan pembatalan putusan arbitrase a quo oleh Majelis Hakim Pengadilan Negeri Jakarta Pusat adalah tindakan yang keliru, putusan pembatalan tersebut menjadi preseden yang buruk, menimbulkan kesan negatif terhadap pandangan berarbitrase dan penanaman modal asing di Indonesia. Terhadap kasus ini, Majelis Hakim Mahkamah Agung yang dalam putusan

\footnotetext{
${ }^{13}$ ASEAN Integration Report 2019.
} 
Peninjauan Kembali untuk tetap pada sikapnya menyatakan bahwa Pengadilan Negeri Jakarta Pusat tidak memiliki kewenangan untuk membatalkan putusan arbitrase a quo adalah putusan yang tepat dan menjadi preseden yang baik. Putusan Mahkamah Agung mencerminkan masih adanya kepastian hukum dalam berarbitrase dan penanaman modal asing di Indonesia, mengingat bahwa kepastian hukum dalam pelaksanaan putusan arbitrase adalah unsur yang sangat berpengaruh terhadap kemauan untuk melakukan perjanjian arbitrase dengan pihak Indonesia, maupun penanaman modal asing di Indonesia.

\section{Penutup}

Tindakan

PERTAMINA

mengajukan gugatan pembatalan terhadap putusan majelis arbitrase Jenewa, Swiss tanggal 18 Desember 2000 menunjukkan sikap yang tidak kooperatif dan tidak menghormati asas pacta sunt servanda, sebagaimana sikap dan asas yang harus ada dalam setiap kontrak. Sikap PERTAMINA juga tidak sesuai dengan jiwa daripada asas final and binding dalam berarbitrase. Terhadap gugatan tersebut, tindakan Pengadilan Negeri Jakarta Pusat yang memutuskan batal putusan arbitrase a quo menambah kompleksitas perkara, namun tidak menghambat pelaksanaan daripada putusan arbitrase tersebut.
Pengadilan Negeri Jakarta Pusat bukan merupakan pengadilan yang berwenang untuk membatalkan putusan arbitrase tersebut, dikarenakan putusan tersebut digolongkan sebagai putusan arbitrase asing yang bahkan tidak diajukan pelaksanaannya di Indonesia.

Tindakan Majelis Hakim

Pengadilan Negeri Jakarta Pusat membatalkan putusan arbitrase a quo adalah tindakan yang keliru, putusan pembatalan tersebut menjadi preseden yang buruk, menimbulkan kesan negatif terhadap pandangan berarbitrase dan penanaman modal asing di Indonesia. Tindakan tersebut tidak sejalan dengan asas daripada penanaman modal Indonesia, yaitu kepastian hukum sebagaimana asas pertama dalam Undang-Undang Nomor 25 Tahun 2007 tentang Penanaman Modal. Padahal kepastian hukum merupakan indikator pertimbangan yang penting bagi pemilik modal sebelum menanamkan modalnya. Namun Majelis Hakim Mahkamah Agung yang dalam putusan Peninjauan Kembali untuk tetap pada sikapnya menyatakan bahwa Pengadilan Negeri Jakarta Pusat tidak memiliki kewenangan untuk membatalkan putusan arbitrase a quo adalah putusan yang tepat dan menjadi preseden yang baik. Putusan Mahkamah Agung mencerminkan masih adanya kepastian hukum dalam berarbitrase dan penanaman modal asing di Indonesia, 
mengingat kedua unsur tersebut sangat penting dan berpengaruh.

Dalam menyelesaikan perkara yang timbul daripada kontrak, maka ada baiknya penyelesaian dilaksanakan dengan berdasarkan perjanjian sebagai landasan yuridis disamping peraturan perundang-undangan yang ada. Penyelesaian perkara juga dibutuhkan sikap kooperatif, mentaati kesepakatan yang telah dibuat, serta asas-asas dalam pilihan penyelesaian sengketa sebagaimana telah diperjanjikan. Demikian suatu proses penyelesaian sengketa terkait penanaman modal asing, sangat mempengaruhi keinginan pemilik modal untuk menanamkan modalnya di suatu negara.

Sebagaimana suatu kontrak yang telah dibuat adalah mengikat dan wajib dilaksanakan, dalam hal apabila terjadi sengketa maka diupayakan penyelesaian yang dengan tata cara yang paling efektif dan tidak berkepanjangan

\section{Bibliografi}

\section{Buku :}

Anita D.A Kolopaking, 2013, Asas Iktikad

Baik Dalam Penyelesaian
Sengketa Kontrak Melalui
Arbitrase, PT Alumni, Bandung.

ASEAN Integration Report 2019.

Muhammad Syaifuddin, 2016, Hukum Kontrak : Memahami Kontrak dalam Perspektif Filsafat, Teori, Dogmatik, dan Praktik Hukum, CV MANDAR MAJU, Bandung.

Rajagukguk, Erman, 1995. Peranan Hukum dalam Pembangunan Ekonomi, Jilid 2, Jakarta: Universitas Indonesia.

\section{Jurnal :}

Ni'matul Huda. 1996. "Penerapan Prinsip Kekebalan Negara Terhadap Badan Usaha Milik Negara", Jurnal Hukum, 3 (5).

\section{Putusan Arbitrase:}

Putusan Arbitrase Jenewa, Swiss tanggal 18 Desember 2000 antara Karaha Bodas Company VS. PERTAMINA dan PLN.

\section{Pidato Pengukuhan Guru Besar:}

Budiman Ginting, 2008, "Kepastian Hukum dan Implikasinya Terhadap Pertumbuhan Investasi di Indonesia", Pidato Pengukuhan Jabatan Guru Besar Tetap dalam Bidang Ilmu Hukum Investasi pada Fakultas Hukum Universitas Sumatera Utara, Medan, 20 September. 